\title{
Effect of Principal Managerial Competence on Quality of SBM Implementation in UPT Elementary Schools District of Depok, Sleman
}

\author{
Jajuk Triningsih and Muhyadi
}

Graduate School, Yogyakarta State University, Yogyakarta, Indonesia

\section{Abstract}

This study aims to find the effect of principal's managerial competencies on the quality of school-based management implementation.

Managerial competency is one of the competencies that must be possessed by a school principal. As an education manager, the principal must be able to manage all the resources that the school has for educational purposes. The principal has an understanding of the goals of education, has a forward-looking outlook, and realizes the potential of the school to become a force to achieve goals for education.

School-based management is the embodiment of one of the educational reforms that

Corresponding Author:

Jajuk Triningsih

triningsihjajuk@yahoo.co.id

Received: 2 May 2019

Accepted: 19 June 2019

Published: 3 July 2019

Publishing services provided by

Knowledge E

(c) Jajuk Triningsih and

Muhyadi. This article is

distributed under the terms of

the Creative Commons

Attribution License, which

permits unrestricted use and

redistribution provided that the

original author and source are

credited.

Selection and Peer-review under the responsibility of the ICMEd

Conference Committee. provides opportunities for schools to provide good education services for students. Improve leadership skills, administrative management, and budget planning followed by transparency and accountability, as well as the participation of parents and the community, making learning conducive. Principals with good managerial competencies will make it a school leader who has good quality, which is one of the reasons that influence the occurrence of a good teaching and learning process at each level of the education unit. Having good managerial competence brings impact on the implementation of quality school-based management.

Through library research and research, a theoretical basis, framework and research questions are reviewed. This study describes the influence of principals' competence on the quality of school-based management implementation. Making quality schools based on government regulations that are demonstrated by the ability of school principals to utilize all school strengths and encourage school members to be more active in improving school quality.

Keywords: competence 1; managerial 2; headmaster 3; school based management 4.

\section{Introduction}

The application of autonomy from the center to the regions has an impact on the world of education. Schools also get autonomy to regulate the course of teaching and learning activities as well as everything related to them. In Indonesia, autonomy is called 
The underlying concept is because schools are institutions that serve educational services at the community level. The school principal as the administrative administrator, manages and develops, also supervises and is accountable for the implementation of education and therefore has a strategic role.

Schools can run and develop well or not depend on many things, one of which is the role of the principal. To realize an effective school, it takes the headmaster who has an understanding of the goals of education, has a vision for the future, and is able to actualize all the potentials to become a strength that synergizes in achieving educational goals. (Kompri, 2015: 5)

The quality of school leaders and school managers is one of the significant factors affecting the quality of the learning process at all levels of the education system and in each type of school. Because it also has an impact on the initiative of staff activities and collaboration with other communities and institutions. (Bitterovaa et. Al., 204).

The principal as the highest manager determines the strategy in achieving educational goals. Then the strategy is translated into a work program. Next, the implementation of work programs is carried out by all teachers and employees, thus creating an organizational system that continues to move to achieve the goals. (Rusdiana "2015: 17). Responsibility in determining sfrategi shows the role central school principal in terms of directing the goals to be achieved by the school. Of course all teachers and employees and all school members must support and get involved in achieving the educational goals by implementing each work program that has been set.

Principals who have management skills can be seen in the ability to delegate tasks to other teachers according to their talents and abilities. Motivate dialogue between staff members and students so that staff members and students are motivated to work optimally. Teachers must be involved in program planning and treat all teachers and students fairly and impartially without taking into account their gender, religion or ethnic background. (Zavena \& Thinguri, 2017)

Providing extensive authority to schools in developing their various potentials also requires an increase in the ability of principals in various aspects of management so that the school is able to realize the vision and mission brought by the school. Therefore, principals are required to have high management and leadership skills in order to be able to build effective schools that are characterized by indicators as follows a) high learning and learning effectiveness; b) Strong and democratic leadership; c) Effective and professional education personnel management; d) Growing quality culture; and e) smart, compact and dynamic teamwork. (Mulyasa 2017: 7) 
In the implementation of the Principal Competency Test at the national level, 44.43 were obtained for the elementary school principals (Education, Youth \& Sports Office in Yogyakarta Special Region, 2015). Based on these data, it will be investigated on how much managerial competence of principals has an influence on the quality of school-based management implementation.

\section{Literature Review}

School-based management in concept is a change in formality from centralization to decentralization and redistribution to decision-making power, where at the school level decision makers are also heads of schools, teachers, parents and other members of the school community. (Kiragu et al. 2013: 1167). The involvement of parents and the willingness of teachers to take action to increase their professionalism capacity is able to change the dynamics of school management. (Heyward, et al 2011: 2).

School-based management increases the task of leadership, better administrative planning due to transparency and accountability, parents and communities are more involved and participate in school programs so that conditions for better and more appropriate learning are created. Overall, the evidence shows: a) school-based management policies change school dynamics; b) mobilize parents or teachers to be more involved; c) giving a positive impact reducing the rate of repetition, failure rates, and dropout rates. (Hermosilla, et al. 2014)

In order for the implementation of school-based management to be successful, it takes the role of the principal to manage the school in accordance with the principles of school-based management. Beare and friends (2018: 18) argue that principals are instructional, first and foremost leaders. In terms of school leadership and the quality of the role of principals overcoming their role in managing schools with challenges to basic resources (eg quality of facilities owned by schools, learning and teaching materials, funding) and in enactment of basic management tasks. Re-structuring will increase the responsibility and accountability of the principal, shifting expectations from the administrative role of the bureaucracy that focuses on carrying out orders and adhering to administrative regulations from higher authorities towards ministers that include leadership to improve and maintain school quality. (Hermosilla, et al. 2014)

If a principal has good management skills, he will be able to arrange for teachers and students to work as a team. This encourages effective implementation of school programs that lead to improved performance to achieve the targets set. If management 
skills are utilized effectively there will be a clear performance management system and a cooperative environment in the school. (Zaveria \& Thinguri, 2017)

Managerial actions that can be carried out to have more competitiveness in the education market are increasing autonomy in institutions, implementing practices, structures, new and innovative techniques for developing and implementing marketing strategies, improving the quality of teaching staff training. While the effective means to develop educational institutions are: consensus and responsible action, the function of the partnership of school-family-community education, staff and the motivation of the school community, as well as implementing innovative strategies. (Manea, 2015: 314)

Rapid development in all fields including in the field of education, requires the principal to be professional. Each school principal is faced with the challenge of developing directed, planned and continuous education to improve the quality of education. So the principal must also have a vision and mission, as well as a quality-oriented management strategy. (Mulyasa 2013: 25)

\section{Material \& Methodology}

This study uses a quantitative approach with survey research methods, carried out in the UPT elementary schools in Depok District, Sleman Regency. The number of respondents used as research was 48 principals. Retrieving data using a closed model questionnaire with a scale rating scale measurement model, provided 4 (four) alternative answers. The steps taken in the data analysis techniques are descriptive analysis, prerequisite test and regression.

\section{Results and Discussion}

\subsection{Result}

The principal managerial competency variable has 4 sub-variables, namely: (a) planning, (b) organizing, (c) implementation, and (d) supervision. The results of the research obtained from the sub variable managerial competence of the principal are as follows.

Based on the table, it can be seen that the head of elementary School UPT in Depok District, Sleman Regency has a very good level of managerial competence. Excellent managerial competence in managing schools by planning activities, developing organizations effectively, carrying out tasks that are their responsibility and overseeing school programs. 


\begin{tabular}{|l|l|} 
No. & $\begin{array}{l}\text { Competency sub variable } \\
\text { Principal Management }\end{array}$ \\
\hline 1. & Planning \\
\hline 2. & Organizing \\
\hline 3. & Implementation \\
\hline 4. & Supervision \\
\hline & Total \\
\hline & Average
\end{tabular}

$\begin{gathered}\text { Achievement } \\ \text { Score }\end{gathered}$
164
148
147
165
624
156

Percentage (\%)

85,42

77,08

76,56

85,93

81,25

The variable of school-based management implementation has 5 sub-variables, namely: (a) independence, (b) cooperation (c) forms of participation, (d) openness, and (e) accountability. The results of the research obtained from the sub-variables of schoolbased management implementation are as follows.

$\begin{array}{ll}\text { No } & \begin{array}{l}\text { Sub-variable } \\ \text { Implementation of SBM }\end{array} \\ 1 & \text { Independence } \\ 2 & \text { Cooperation } \\ 3 & \text { Form of participation } \\ 4 & \text { Openness } \\ 5 & \text { Accountability } \\ & \text { Total } \\ & \text { Average }\end{array}$

\begin{tabular}{|c|c|}
\hline Average Score & Percentage (\%) \\
\hline 177 & 92,19 \\
\hline 175 & 91,15 \\
\hline 158 & 82,29 \\
\hline 177 & 92,19 \\
\hline 178 & 92,70 \\
\hline 865 & \\
\hline 173 & 90,10 \\
\hline
\end{tabular}

Based on the table it is known that the implementation of SBM in the Elementary School UPT Depok District Sleman Regency has very good quality on reporting and accountability.

Through the calculation, the significance value of deviation from linearity of managerial competence $(X)$ on the implementation of SBM $(Y)$ is 0.846 . Because $0,846>0,05$ then it is declared linear. $X$ correlation coefficient value is 0,779 . This means the principal managerial competency variable $(\mathrm{X})$ and the implementation of SBM $(\mathrm{Y})$ have strong level of relationship. In addition, the coefficient of determination $\left(R^{2}\right)$ is 0,599 . Thus the magnitude of the contribution of the principal's managerial competency variable $(X)$ to the implementation of SBM $(Y)$ is $59,90 \%$ while the remaining $40,10 \%$ is influenced by other factors.

\subsection{Discussion}

The results of the study indicated that there was a positive and significant effect of the principal managerial competencies on the quality of SBM implementation. In order for 
the implementation of SBM to be successful it requires the participation of the principal who can manage the school in accordance with SBM principles namely independence, cooperation, forms of participation, openness, and accountability. The principal is the instructional, first and foremost leader. As a principal manager needs to have skills in planning, organizing, implementing, and supervising.

School-based management is a manifestation of educational reform. By giving authority to manage schools independently in order to implement governance so that it can be a means of improving the performance of teachers and employees, providing opportunities for groups related to schools to be directly involved, and so that people are better understood about education. (Mulyasa 2009: 24)

Although school-based management has been introduced since 2000 , in its implementation the implementation of school-based management still faces problems. Problems encountered in implementing school-based management from the most consecutive are financing management, educator management and cultural and school management management education staff, student management, facilities and infrastructure management, public relations management and learning management. (Mustiningsih, 2015: 503-504). From the results of the research that has been conducted, there are still high problems in the implementation of school-based management, especially in elementary schools.

In order for the implementation of school-based management to succeed, it requires the participation of school principals who can manage schools in accordance with the principles of school-based management. Therefore a professional headmaster is needed to be able to effectively and efficiently plan, implement and evaluate policies and changes that occur. Effective school search, the transition to school-based management, emphasis on development planning in schools, ensuring the quality of school education, and the implementation of various rearrangement programs in schools are typical examples of the reform movement's efforts in schools.

The essence of school-based management is the shift that occurs in school management from external control to self-management or school-based management. Central management often skips school-based needs; ineffective and too rigid to develop school-based initiatives and meet changing school-based needs. Decentralization of power from central authorities to school level, school autonomy and self-management, and the participation of school constituents are strongly encouraged to facilitate schoolbased initiatives for school development and effectiveness. (Cheng. 2012) 
A school principal must have the qualifications as stipulated in the regulations of the Minister of National Education, and also have competence. There are five competencies that the principal must have, one of them is managerial competence. Managerial competence makes the principal as an education manager who is responsible for the smoothness of education and teaching in the place he leads.

With good managerial skills, the principal will be able to coordinate educators, education staff and students into a team. Implement school programs that lead to improved performance that are set to reach targets effectively. Principals who are effective in management, will make the performance management system clearer so that a cooperative environment in schools can be created. (Zaveia \& Thinguri, 2017)

The principal will be able to carry out his duties well if he is able to understand, master, coordinate the implementation and oversee the resources to achieve the objectives. If the principal is able to coordinate, mobilize and harmonize all the resources that the school has, it means that the principal has good managerial competence. Good managerial skills will support programs from schools in implementing school-based management.

Innovation in management is defined as the discovery and implementation of new practical, structure, techniques or process management for the highest level of development in the field and that is achieved to contribute to achieving organizational goals. (Manea, 2015: 314)

Principal leadership and management skills contribute a lot to the effectiveness of school management. Schools need leaders who have a multidimensional management style that leads to improvement and success in school. Whatever the form of the educational unit, however the role of the principal remains a 'professional leader'. The principal has the task of responding to the policies set by the government while ensuring that what the school needs is fulfilled. (Steward, 2014)

\section{Conclusion}

School-based management policies provide a dynamic change in schools, moving parents more involved in school programs, has a positive impact on reducing the level of students who repeat failure rates and drop out students. Also shows positive results for graduates. Changes to school management provide clear changes and demand the superiority of school principals. Schools are given a large portion to manage the resources owned by the school. Furthermore, the school uses the assets it has in accordance with the priorities it needs and cares about the surrounding needs. 
After the freedom is left to the school to manage it4, the school must be independent in exploring, making programs and holding up the resources used by the government and the community. There is expected involvement from parents and the community at school, namely that parents and the community pay more attention to helping and controlling the management of education as well as formulating decisions about education.

With the participation of parents and the community, there will be more commitment to the school. This makes the management of schools more accountable and the monopoly eliminated.

Two things can be used as reasons for implementing school-based management, namely schools increasingly show better management and governance and enable better conditions for teaching and learning. Professional school principals must be able to realize these two reasons for fulfilling the quality of good school-based management implementation.

\section{References}

[1] Beare, Hedley., Caldwell, Brian J. Millikan, Ross H. (2018). Creating an excellent school Some New Management Techniques., Routledge Library Editions: Education Management. Retrieved from. https://www.taylorfrancis.com/books/9781351041539

[2] Bitterováa, H., Haškováa, A., \& PisoĖová, M. (2014) School leader's competencies in (2014). Procedia - Social and Behavioral Sciences 149. Retrieved from http:// creativecommons.org/licenses/by-nc-nd/3.0/. doi: 10.1016/j.sbspro.2014.08.170

[3] Cheng, Yin Cheong. (2012). School effectiveness and School-based management: A mechanism for development. R Routledge Taylor \&. Francis Group London And New York.

[4] Duhou-Ibtisam Abu. (2002). School based management. Jakarta: Logos

[5] Hermosilla, M.F., Anderson S., \& Mundy K. (2014). Education Management and Leadership: A Rapid Review of the Literature, Ontario Institute for Studies in Education, University of Toronto. Retrieved from. https://www.oise.utoronto.ca/cidec/UserFiles/File/Website/ Rapid_Review_Education_Management_and_Leadership_june_30_final.pdf

[6] Heyward, M., Cannon, R.A., \& Sarjono. (2011). Implementing school-based management in Indonesia. RTI Press publication No. OP-0006-1109. Research Triangle Park, NC: RTI Press. Retrieved [date] from http://www.rti.org/rtipress. 
[7] Kiragu, J. W., King'oina, J. O., \& Migosi J. A. (2013). School - based management prospects and challenges: a caseo of public secondary schools in murang'a south district, kenya. Journal of Asian Social Science. Retrieved from http://www.aessweb. com/journal-detail.php?id=5007

[8] Kompri. (2015). Manajemen sekolah orientasi kemandirian kepala sekolah. Yogyakarta: Pustaka Pelajar.

[9] Manea, Adriana D. (2015). Innovation in the management of educational institutions. Procedia - Social and Behavioral Sciences 209 (2015) 310 - 315. Retrieved from https://mafiadoc.com/innovation-in-the-management-ofeducational-sciencedirectcom_5aa4732b1723ddffac966b76.html

[10] Mendels, P. \& Mitgang, L.D. (2013). Creating strong principals. Educational leadership. The Wallace Foundation. ASCD / www.ASCD.org

[11] Mulyasa, E. (2009). Manajemen berbasis sekolah. Bandung: PT Remaja Rosdakarya. [12] _ (2013). Menjadi kepala sekolah profesional. Bandung: PT Remaja Rosdakarya.

[13] _ (2017). Manajemen dan kepemimpinan kepala sekolah. Jakarta: PT Bumi Aksara.

[14] Mustiningsih. (2015). Masalah implementasi manajemen berbasis sekolah di sekolah dasar. Jurnal Manajemen Pendidikan.Universitas Negeri Malang: Volume 24, Nomor 6.

[15] Rusdiana, H.A. (2015). Pengelolaan pendidikan. Bandung: CV Pustaka Setia.

[16] Steward, Julia. (2014). Sustaining emotional resilience for school leadership. School Leadership \& Management, 2014 Vol. 34, No. 1, 52-68, Retrieved from http://dx.doi. org/10.1080/13632434.2013.849686 DOI: 10.1080/13632434.2013.849686

[17] Zaveria, K.W. \& Thinguri, Ruth W. (2017). Critical Analysis Of The Relationship Between Principals' Management Skills And Team Work In Public Secondary Schools In Kenya. European Journal of Education Studies, Volume 3 Issue 1. Retrieved from. https: //oapub.org/edu/index.php/ejes/article/view/416/1115, doi: 10.5281/zenodo.225451 